Multiplicités des approches en anglais de spécialité

\title{
CLIL in higher education: the (perfect?) crossroads of ESP and didactic reflection
}

\section{Gail Taillefer}

\section{(2) OpenEdition}

1 Journals

Electronic version

URL: https://journals.openedition.org/asp/3290

DOI: 10.4000/asp.3290

ISSN: 2108-6354

\section{Publisher}

Groupe d'étude et de recherche en anglais de spécialité

\section{Printed version}

Date of publication: 1 March 2013

Number of pages: $31-53$

ISSN: 1246-8185

\section{Electronic reference}

Gail Taillefer, "CLIL in higher education: the (perfect?) crossroads of ESP and didactic reflection", ASp

[Online], 63 | 2013, Online since 07 October 2014, connection on 07 December 2022. URL: http:// journals.openedition.org/asp/3290 ; DOI: https://doi.org/10.4000/asp.3290

This text was automatically generated on 2 November 2020.

All rights reserved 


\title{
CLIL in higher education: the (perfect?) crossroads of ESP and didactic reflection
}

\author{
Gail Taillefer
}

\section{Introduction}

1 The major aim of the European Higher Education Area, created within the framework of the Bologna Process, has been to encourage internationalisation of higher education (HE). Worldwide rankings of universities in recent years, stressing quality teaching in addition to research, have brought examples of effective practice to light, thereby raising awareness of quality issues (European Association for Quality Assurance in Higher Education, ENQA) and stimulating competition among institutions and countries, all the more so in the context of a globalised labour market. With increasing student and teacher mobility dating from the beginning of the Erasmus programme in 1987 and the development of virtual exchanges via "new" educational technology, content and language integrated learning (CLIL) has now become a key strategy in the international HE playing field. And as such, it has become an object of both teaching and research.

2 Various contexts, notably where English is the language of teaching and learning, have given rise to examples of effective practice and theoretical models from around the world. A chronological and thematic overview can date back to the mid-1990s. Flowerdew and Miller (1995), observing British programmes taught in Hong Kong, showed through a multi-dimensional ethnographic study how cultural issues (ethnic, local, academic, disciplinary) impact lecturing in L2. Within the context of the Erasmus programme, Maiworm and Wächter (2002) catalogued programmes taught through English across Europe, analysing trends and success factors. The authors updated the picture in 2007 (Wächter \& Maiworm 2008) of what had been seen earlier to be a "marginal phenomenon". While CLIL was reported to be on the rise across Europe, the 
Netherlands, Finland and its northern neighbours offered the greatest number of programmes, nearly 80 percent of which were postgraduate (Master's), primarily in engineering, business and management. A Northern European CLIL perspective was given by Hellekjaer and Wilkinson in 2003, pointing out that true dual focus CLIL (where content and language reinforce each other on equal footing) is not common, and yet seems to be the optimal approach. At the same time in France, Mémet (2003) empirically explored the motivational factor in CLIL students, distinguishing between graduate and undergraduate levels. The same year, further to the 24th GERAS colloquium on the theme of "Transfert(s)", Wolff (2003) explored the question of whether transfer of knowledge and of language are ensured in a CLIL environment (yes, if certain conditions are respected). An early, and key, author on CLIL in primary, secondary and vocational education, Marsh contributed to the question in HE as part of the European Language Council ENLU project (European Network for the promotion of Language learning among all Undergraduates, 2004-2006). A pertinent discussion brief (Marsh \& Laitinen 2004) offered insights based on an empirical consultation process: for example, the role of HE language specialists in implementing CLIL, assumptions of language proficiency on the part of content teachers (specialists of non language disciplines) and students, teaching methodologies (interactional vs. transactional) in regard to the heavy cognitive load of teaching and learning by CLIL, on the specific role of English, institutional language policies and quality assessment. From a cultural perspective, in 2005, Yamazaki linked theoretical anthropological analyses and Kolb's learning model to empirical comparative studies to show how particular national cultures relate to particular learning styles or abilities. Furthering this direction of inquiry, Joy and Kolb (2009) reported how Hofstede's (1991) classic dimensions of collectivism, uncertainty avoidance, power distance (by gender) and masculinity/ femininity and Hall's (1977) notion of present/past/future orientation translate as more abstract and conceptual learning styles or, on the contrary, as more reflective learning styles given to active experimentation.

Going back to 2006, Coleman published a European-wide overview of English-medium teaching, affirming that "CLIL has not yet been widely adopted in HE" (2006: 5). He pinpoints the reasons behind the growing enthusiasm for this approach, its "Englishisation", and astutely warns of predictable problems (staff and student language skills, inter/cultural issues, assessment, institutional involvement) - many of which are apparent in the French context, and will be discussed below. Coleman's impetus led to the creation in 2010 of the Integrating of Content and Language in Higher Education Association (ICLHE), whose third annual conference will take place in April 2013, addressing the interface between content and language in HE. Also in 2006, Räsänen and Klaassen, experienced CLIL researchers and teachers from, respectively, Finland and the Netherlands, explored the specific impact of teaching staff competence in CLIL in terms of expected learning outcomes for students. In order for the latter to master the language and communication skills necessary for graduates in their given domain, content teachers are called on to provide an environment allowing for parallel language and content knowledge construction. This generally entails in-depth and coordinated pedagogical, and political, reflection on the part of all stakeholders (teachers, students, institutions).

4 In 2009 (proceedings from a journée d'étude LAIRDIL in 2007), Tudor offered a "constructive but nonetheless critical perspective" on CLIL in HE (2009: 24). Focusing first on the rationale for CLIL tertiary education, he went on to offer insight into 
various contexts across Europe (Belgium, Hungary, Bulgaria, Switzerland and Denmark). From these case studies, he concluded with the importance of institutional language policy and of serious reflection on the nature and practical aspects of quality CLIL (student, content and language teacher and institutional variables; see also Tudor 2008). During the same journée d'étude in 2007, Taillefer (2009a) explored the offer of CLIL at that point in time in France, as well as the beginnings of French research into the theme. The proceedings also describe a Canadian ("immersion") and a Finnish model of CLIL (Taillefer 2009b, c), and summarise the discussion between content teachers (physics, mathematics, computer science, law, economics) and language teachers (English, Spanish, French as a foreign language) in terms of advantages of CLIL, risks and challenges (Taillefer 2009d). On the particular question of CLIL and language policy, Tudor $(2006,2007)$ offers further insight, looking at trends, principles and practice.

While the context of the present reflection is European, and more particularly, French, mention must be made of the recent Canadian work in CLIL. Primary and secondary "immersion" - of Anglophone children in French-language education - dates back to the early 1970s. In 2006, the bilingual University of Ottawa answered the call of the federal (and to a lesser extent, provincial) government to further this pedagogical approach in HE. Indeed, high school immersion graduates overwhelmingly enrol in English-language programmes, "losing" the benefit of their years of immersion schooling. The various programmes developed at the university's Official Languages and Bilingualism Institute/Institut des langues officielles et dubilinguisme (OLBI/ILOB) can offer much inspiration to European educators, regardless of the linguistic context of any particular country. Among the many publications, particularly in the Cahiers de l'ILOB/OLBI Working Papers, interested readers can explore WeinbergandBurger (2007), an in-house OLBI manual written for language specialists teaching modules in parallel to content classes ("adjunct" CLIL); Weinberg, BurgerandHope (2008) on evaluating the effectiveness of CLIL; Knoerr (2010) on the role of the language teacher in CLIL (activities and strategies) and the development of bi-/multilingual competence; Burger et alii (2011) on programme evaluation and pedagogy.

6 A recent - and key, given the participation of HE institutions from ten countries across Europe - contribution to the CLIL scene was made by the Language Network for Quality Assurance project (LANQUA, see References for site), 2007-2010. Funded by the Lifelong Learning Erasmus Network of the European Union, the project brought together sixty partner institutions in five areas " languages in higher education [...] and to reflect on how a subject practitioner-led approach to quality assurance can inform quality assurance processes and enhance the quality of the learning experience for students" (LANQUA home page). The CLIL subgroup included teachers and researchers from (alphabetically) Austria, Cyprus, Finland, France, Hungary, Italy, Luxembourg, Romania, Spain and Switzerland who, together, described variations on the theme across Europe presented in the form of a continuum from less to more effective practice. This continuum was exemplified by five empirical case studies and a discussion of prerequisites and quality issues for successful implementation of CLIL. Resources for the entire project, including CLIL, are available on the site as the LANQUA "Toolkit", consisting of a Quality Model to guide practice and reflection, a detailed Frame of Reference summarising effective teaching, learning and assessment practices, the case studies, ${ }^{2}$ further Guidance notes and links 
to other documents. Specific notions pertinent to the question of CLIL and didactics within ESP are developed below, but as observed in earlier studies, it was apparent from the LANQUA project that CLIL is more frequently implemented on a Master's level and that a marked variation exists, quantitatively and qualitatively speaking, between Northern and Southern European countries. The latter point is in no way a value judgement, but concretely translates questions of official bi-, tri- or monolingualism, national languages which are more or less widely spoken, and more or less centralised traditions of HE. A European project carrying on from LANQUA, based in Romania and focussing on developing a framework for international Master's level education in that country, has given rise to two further publications by former LANQUA members (Räsänen 2011a; Taillefer 2011) on communication in international/intercultural classrooms and on change management. In a similar spirit, LANQUA partners led a round table at the 2010 conference of the European Society for the Study of English (ESSE), putting forth European-wide research and practices and raising pertinent CLIL questions to a wide audience (Hansen-Pauly \& Greere 2011).

In the same time frame as the LANQUA project, Bartik et alii (2009) conducted an indepth empirical study at the University of Cordoba, from which they were able to offer state-of-the-art recommendations for implementing CLIL in HE. The specificities of this pedagogical approach were compared with mother tongue teaching and learning, and a warning call was sounded, echoing that of Marsh and Laitinen (2004) and Coleman (2006): among other issues to be alert for, the involvement of HE language specialists and their close collaboration with content specialists, an appropriate CLIL methodology in light of the increased cognitive load, the appropriate level of vehicular language competence for both teachers and students (for the latter, an absolute minimum of B1+ on the Common European Framework of Reference for Languages, CEFRL). At stake is a decrease in the quality of both teaching and learning - the very opposite of the spirit of the Bologna process. The authors conclude with two very significant contributions: suggestions for developing CLIL "guides" for both students and teachers, and grids for assessing classroom management, teaching and the nature of exams. Two years later, Räsänen (2011c) reinforced the holistic nature of successful CLIL ("promises and challenges") in a summary slide presentation at a European conference on "Multilingual Competences for Professional and Social Success in Europe". Finally, most recent contribution, and one which brings us back to the French context, is the publication by Causa et alii (2012), further to a journée d'étude DILTEC in 2009, shedding light on several of the unresolved CLIL questions that aforementioned studies have raised for research in didactics in the French Lansad sector.

The CLIL question continues to arouse research and pedagogical interest in France. Following up on the two aforementioned journées d'étude $(2007,2009)$, thePôleSHS at Université Joseph-Fourier in conjunction with LIDILEM organised in early September 2012 the "Premières Rencontres Langues et Sciences, entre politique linguistique et politique scientifique : enseigner sa discipline dans une langue étrangère", focussing on the linguistic stakes of international programmes. Just a few weeks following the exchanges, the Director of the university language service (personal communication) was called in to consult on setting up a diplôme d'université on adjunct CLIL. Finally, in October 2012, a call for papers was put out by Recherche et pratiques pédagogiques en langues de spécialité Cahiers de l'APLIUT for the October 2013 issue of the journal on "Teaching and learning through CLIL: what is at stake in the non-specialist language sector?". 
Given this overview of both national and international research into theory and practice, France comes across as being a relatively recent player in the field of HE CLIL. In 2006, Coleman wrote: “...in France, where foreign policy for so long fought to maintain French as an alternative lingua franca [...], there is now acceptance of the need for more English-medium university courses" (2006: 8). Insight into examples of CLIL implementation in this country will be given below, but in light of the longstanding international recommendations made for effective practice, it would seem that France reflects less than optimal awareness of key quality issues.

Thus, in the spirit of formative assessment and quality enhancement as developed in the literature and as inspired by the Bologna process, our objective is to approach the question of CLIL in French HE from an analytical perspective not of a simple product, but of a process of change management. In so doing, we would hope to continue to raise language awareness on local and national levels to avoid (further) classic CLIL pitfalls. We will share with members of the ESP community insights into recent European work on CLIL and suggest by means of a SWOT analysis (strengths, weaknesses, opportunities and threats) ways to integrate pertinent reflection and practice at the crossroads that CLIL represents between disciplinary content and ESP.

\section{CLIL in theory and in practice}

\section{The message of quality assurance}

11 CLIL is also known as second/foreign language-mediated higher education (and in the secondary sector, as Content-based instruction, CBI). ${ }^{3}$ It is implemented in the field across a wide range of disciplines, from hard sciences and medicine through business and engineering to humanities. It is found in modular as well as in full degree programmes at both undergraduate and graduate levels, although the latter is the most common context. While not restricted to English, the Englishisation (Coleman 2006) of CLIL is a fact, and raises questions of multi- and plurilingualism, not only in multilingual countries. The definition of CLIL proposed by the LANQUA project is that of: "an umbrella term for all those HE approaches in which some form of specific and academic language support is offered to students in order to facilitate their learning of the content through that language" (LANQUA Frame of Reference: 4). The underlying "virtuous circle" concept is that knowledge and understanding cannot be constructed or evaluated without the language of the discipline in question, and at the same time, that language can only be learned through using it in authentic and relevant contexts. CLIL may also involve the broader notion of promoting multilingual and multicultural competence during content learning.

12 Practically speaking, CLIL is seen in the field to "vary on a continuum from disciplinespecific and pre-content [language] support to full integration of language and content" (LANQUA Frame of Reference: 4). ${ }^{4}$ In foreign-language mediated education, the zero degree of non-CLIL corresponds to a context of Two solitudes, ${ }^{5}$ where language contact is incidental and unsystematic (for example, visiting experts or occasional lectures) and where there is neither concern for language learning nor pedagogical collaboration between content and language teachers. Next comes pre-CLIL, or "classic" LSP taught with no systematic collaboration with content teachers. Partial CLIL may be either language-oriented, often taught pre-sessionally in the spirit of 
language for academic purposes targeting specific disciplines, or content-oriented perhaps the most common scenario - with content courses simply taught by a subject specialist in the target language to multilingual and multicultural groups and where language learning, generally with no explicit aims and criteria, is expected to happen through osmosis. At the top end of the scale are models of adjunct CLIL, where language support parallels content study with specified goals in both cases, and finally, what experts (Marsh \& Laitinen 2004; Bartik et alii 2009; Räsänen 2011c), consider to be true dual focus CLIL, where both content and language aims are addressed by a linguistically competent and pedagogically aware subject teacher or by a team of language and content specialists working in close collaboration.

13 As can be deduced from the definition of CLIL and its perception as a continuum, a successful approach in any educational context means clear awareness of the large number of variables pertaining to the different stakeholders. For learners, it is crucial to define and to make explicit the knowledge, understanding and competences that they should acquire and be able to demonstrate. These acquisitions should be specified in terms of learning aims or objectives (broad or specific intended learning) and learning outcomes (demonstrable achievements). ${ }^{6}$ The LANQUA Frame of Reference (7-8) gives extended examples of both objectives and outcomes, but briefly summarised, CLIL students should aim to acquire:

- knowledge of what constitutes multilingual competence in the field-specific and professional domain;

- understanding of the national and international dimensions of the professions in the field (including cultural differences);

- knowledge and understanding of how multilingual and multicultural professional teams, networks and communities operate;

- awareness, knowledge and understanding of target language communication conventions of the professions in the field;

- understanding of the importance of continuously developing one's own professional expertise.

With such knowledge and understanding, students should be able to demonstrate the capacity for:

- mobilising the receptive and productive skills necessary to access, process and critically evaluate information in the field of study;

- mediating between languages and cultures in social and in professional settings;

- communicating in the target language to interact in professional and interpersonal networks;

- communicating orally and in writing - particularly research writing - in the target language in professional and social contexts;

- mobilising appropriate metacognitive skills and strategies.

CLIL Teachers - of both content and language - play, perhaps, the pivotal role in this approach. New demands are made of them, particularly in Southern Europe with its tradition of ex cathedra lecturing in the image of an omniscient "sage on the stage". ${ }^{7}$ As research has shown (Marsh \& Laitinen 2004; Coleman 2006; Weinberg et alii 2008; Bartik et alii 2009; Räsänen 2011a, b), content teachers have a responsibility as role models of discipline-specific language and communication. As such, for example, they must have sufficient communicative competence in the target language to be able to remain true to their own persona and teach with the same spontaneity as they do in L1, switching 
registers, paraphrasing, hedging, being alert to students' level of comprehension, etc. This may mean improving their own language proficiency. A certain amount of personal, language-related risk taking is thus necessarily involved. Content teachers should also be sensitive to both foreign language and intercultural teaching and learning issues (for example, the role of reading, plagiarism and losing face, Flowerdew \& Miller 1995; Taillefer $2005 \mathrm{a}, \mathrm{b}$ ) and to assessment protocols. They may need to adopt new or different pedagogical practices (greater use of visuals, more specific clarifications, new kinds of teaching materials including interactivity and perhaps blended learning approaches...). And, as the literature suggests, they should be capable of and open to collaboration with language teachers in orienting and formulating learning outcomes and in assessing students' oral and written language to distinguish between content mastery and language mastery. A noteworthy example of addressing such concerns head-on is the TACE programme (Teaching Academic Content through English) at the University of Jyväskylä (Räsänen 2011b; also see Räsänen 2011a).

Language teachers, in many cultural contexts, and almost regardless of the nature of CLIL implemented in their institution must also be able to move beyond "traditional" interpretations of their work to understand the role that language and communication play in learning and knowledge construction. This can often mean finding a new, acceptable balance between accuracy and fluency, in the spirit of partial competences described in the Common European Framework of Reference for Languages (Council of Europe 2002: 135). Language teachers must also be alert to special needs of both students and content teachers. And like content teachers, they may need to reconsider their role as one of a "guide on the side", able to cross disciplinary boundaries in collaboration with content teachers to orient and formulate learning outcomes and assessment protocols.

The latter lie at the crossroads of student and teacher CLIL variables, and thus merit special mention, since the nature and practice of evaluation - both of learners' acquisitions and competences as well as the overall quality of teaching and programmes - are very strongly culturally linked. Thus, the varied CLIL contexts observed across Europe reflect the range of assessment types presented in Table 7 of the CEFR (2002: 183), from oral to written, individual to group, formative to summative, self assessment to peer assessment, etc. While content is never "neglected" in the declension of CLIL, language assessment varies from nearly non-existent to full integration with content criteria, as one mark or two, with or without ECTS credits.

Last but not least, the HE institution (be it on a national and/or local level) has its specific role to play in striving for successful CLIL. The first and foremost consideration is recognition of the need for and implementation of a coherent language policy and guidelines, and the clear understanding of the impact that these have on the institution's image. Surely one of the longest standing (since 2004) and best examples of such a policy is that of the University of Jyväskylä (see References). While few countries can compete with Finland on an overall educational level, such highly developed language awareness can serve as an inspiring model. To strive for effective CLIL, both pedagogical and administrative support structures need to be provided for, with appropriate funding and development. Information must generally be made more explicit, keeping in mind an online readership of varying cultural backgrounds and target language reading levels. Proper translations into the target language must be envisaged. Finally, quality assurance indicators must be established and put into 
practice, first in the form of quality assessment - what is the institution trying to do? Why? How? - and then as quality enhancement - why is the chosen approach the best way to reach established goals? How can the institution affirm that this is so? How can improvements be made? The LANQUA project Quality Model (see Quality model on site, listed in References) offers clear and practical guidance from both teachers' and learners' perspectives to support a "bottom-up view of quality assurance" that complements "more formal internal [student and peer evaluations, washback] and external quality assurance processes [AERES, ENQA] in higher education institutions". Key notions are that of the educational context, the reflective practitioner, stages of planning, purpose, implementation, monitoring and evaluation, and adaptation.

A final overview of the interrelation of the different variables pertaining to CLIL main aims, target group, main actors, pedagogical approach, view of language, learning outcomes, assessment - across the continuum model (partial, adjunct and dual focus CLIL) is summarised in clear table form in the LANQUA Frame of Reference (12). To conclude on the theory and practice of CLIL, Räsänen (2011c) yet again offers a succinct summary of the prerequisites for success, according to research:

- clarified, specified and mutually accepted aims at both institutional and individual level;

- role of language and target language development acknowledged as an integral part of instructional design and content delivery,

- programme overtly promoted by institutional policies, including infrastructure, incentives, and systematic staff development in both educational communication and pedagogical skills;

- an interactive and learner-centred pedagogical approach, with authentic, relevant and culturally balanced learning tasks and cross-curricular and cross-disciplinary co-operation;

- instructional approach offers rich language input and practice in appropriate language use, as well as multiple opportunities to process information and construct knowledge;

- multiple forms of assessment and support;

- systematic documentation to improve transparency and quality and to facilitate vertical mobility in line with the Bologna process.

Thus, unless properly planned out, instead of fulfilling its aims in a virtuous circle, as Bartik et alii (2009) affirm, and Marsh and Laitinen (2004) and Coleman (2006) before them, CLIL may well become a vicious circle, putting pressure on stakeholders and resulting in counterproductive frustration and missed opportunities. Concrete examples of CLIL implementation in French HE are given below for ESP professionals to consider in light of models of research-based effective practice. With potential pitfalls in mind, the ESP community can then hopefully encourage informed quality enhancement of CLIL in the French context.

\section{Observations of the French context}

21 As an introductory note, a question of terminology and translation warrants attention. The most common expression, as mentioned above, for the educational context in question is, in English, "content and language integrated learning" and in French, "l 'enseignement d'une matière par l'intégration d'une langue étrangère". In 2004, we suggested what we felt to be a more accurate rendition of the concept of dual focus CLIL, the term "AIMEL" - apprentissage (and not enseignement) intégré (and not par in the sense of "by means of") d'une matière et d'une langue (Taillefer 2004: 118). Unable to trace the origin 
and development of the term EMILE , and seeing that the suggestion made in 2004 has had no repercussions, we can only hypothesize that the use of "enseignement" rather than "apprentissage" is a reflection - conscious or not, wilful or not - of the Southern European ex cathedra, teacher-centred tradition. This orientation, in light of the models of effective practice presented above, sounds a first alarm bell.

That being said, a recent voice to be heard concerning the French CLIL context is research-based. Harking back to the aforementioned words of warning (Marsh \& Laitinen 2004; Coleman 2006; Bartik et alii 2009), Strasbourg sociolinguist Claude Truchot (2010) ${ }^{9}$ underscores the danger of ignoring key issues in foreign languagemediated education. The situation he refers to, corresponding to the CLIL continuum description of content-oriented partial CLIL, is surely the one most often encountered in France:

[Ce] mode de traitement des questions de langues [d'utiliser l'anglais comme langue véhiculaire dans l'enseignement supérieur] s'effectue sans études préalables, sans débats, sans évaluations par les établissements ou les autorités publiques compétentes, sans que d'autres solutions soient recherchées.

He stresses that a critical approach is necessary and concludes by saying: "le constat du décalage entre le niveau en anglais [dans d'autres parties du continent] et celui des pays d'Europe du Nord les poussent [ceux-là] à tenter de le réduire. Certains en font une priorite politique". He concludes by citing the Rapport Attali, prepared for the government in 2008, which states that "...tout élève maîtrise avant la fin de la $6^{\mathrm{e}}$ le français, la lecture, le calcul, le travail de groupe, l'anglais, l'informatique et l'économie" and raises the obvious, unaddressed, question of providing the means to do so.

An example of critically thought-out CLIL can be found at the University of Toulouse-1 Capitole in the bilingual programmes of the Licence en droit: parcours droit et langue anglaise and parcours droit et monde hispanique (see References). A similar programme in Economics and Spanish also existed for a few years. First-hand observation of these programmes and their formative evaluations allows us to affirm that they began as a true joint effort between the Département des Langues et Civilisations and the Faculties, respectively, of Law and Economics. In the absence of a university-wide language policy, this collaboration resulted from the fortuitous - and impermanent working partnership and transdisciplinary perspectives of the key decision makers at the time on departmental, faculty and presidential levels. The turnover inherent at such levels, however, has seen changing priorities in the Faculty of Economics and the end of this undergraduate experience. The programme has continued in the Law Faculty, with formative assessment continuing to iron out certain difficulties (notably the English competency of certain content teachers). Inspired by this model, the University of Toulouse-le Mirail has opened, as of academic year 2012-2013, similar parcours bilingues in undergraduate History and English and History and Spanish (see References).

The absence of any form of university-wide language policy, however - and not surprisingly, as the literature gives us to understand -, also explains the less than optimal content-oriented partial CLIL observed in the Toulouse School of Economics (TSE), a world-renowned research centre. Interviews with management, teaching staff, administration and students, carried out in a climate of confidence in the spirit of seeing how, or if, the language department could be of service to TSE (as was the case in 
the interviews reported in Taillefer 2004), enabled us, in the end, to propose one of the five LANQUA case studies illustrating the CLIL continuum. It stands in neutral, but obvious, contrast to the models from Finland, Luxembourg, Switzerland and Southern European counterpart Italy (LANQUA site: examples-practice). As presented online, the overall picture of "The challenge of CLIL in a French School of Economics" is that of a low level of institutional sensitivity to language issues. Both students and teachers are recruited from around the world, with very few native English speakers in either group. This in itself, of course, is not a problem, as long as both have the necessary language competency, which is easily the case for the great majority of content teachers. ${ }^{10}$ But in spite of the fact that Master's (and doctoral) levels of TSE are taught entirely in English, no explicit language requirements are specified for first year Master's candidates. Direct entry into second year of the Master's programme stipulates only self-assessment ("very good, average, poor") of writing, reading and speaking ability, and specifies that applicants must be "comfortable" with receptive skills. Thirty hours of Economic English (and of French for foreigners) are offered on an optional basis (no credits) in an intensive module at the beginning of the first year of the Master's programme. No other dedicated language support is provided for students and none for staff. Content teachers do, however, work on a one-to-one basis with students on papers and dissertations in English, reportedly taking language into account, and also practice job interviews with doctoral students.

From the true dual focus CLIL perspective that examples of effective practice condone, then, there is very limited formal concern expressed in TSE for language and academic communication in English, and none for intercultural competence (questions of plagiarism, of classroom behaviour), either for students or for teaching staff. The general impression seems to be that, despite the absence of defined learning objectives or outcomes, everyone is coping sufficiently well. Problems reported during interviews - students' difficulties with oral presentations and with written communication which hinders their work from being readily accepted by respected journals, teachers uncomfortable with less than optimal language skills (English, for a few of the older colleagues, or French, for foreign colleagues) - are not officially recognised. Questions of pedagogical methodology pertaining, for example, to appropriate use of oral communication skills and ways to avoid plagiarism were raised by some teachers, but only during interviews. And aside from being asked to teach a minimal number of optional ESP (or French foreign language) hours, language specialists have never been involved in any other capacity.

In the absence of any published, systematic institutional evaluation of this CLIL undertaking, it is difficult to carry out further analysis. But comparison with models of effective practice presented in the literature clearly does not work in TSE's favour. Suggestions of implementing a course in academic writing and of providing language support in the form of individual "coaching" were proposed as feedback from interviews, but were felt to be superfluous. The employment record of TSE graduates is known to be exemplary, but whether, over time, the relative lack of sensitivity to language issues will negatively affect the institutional image remains to be seen.

A further, rather ironic, concrete indication of lack of language awareness in the CLIL context is found in the Campusfrance online brochure Programmes taught in English. This joint effort of the Ministry of Foreign Affairs and the Ministry of Higher Education coordinates and markets CLIL programmes to attract foreign students. The latest 
version $^{11}$ of the catalogue lists more than 600 programmes, $80 \%$ of which are on the Master's level, especially in the fields of Commerce and Management, reflecting Wächter and Maiworm's (2008) findings for Europe in general. While this is certainly evidence of the French desire to internationalise HE, the literature allows us to identify two key language issues which cloud the quality picture. First, it is not far-fetched to expect that programmes taught in English stipulate the required level of language proficiency. Bartik et alii (2009), for example, mentioned above, specify an absolute minimum level of CEFR B1+; many Erasmus exchanges now require proof of a B2 level (personal communication, International Relations Service, University of Toulouse-1 Capitole). But nearly $50 \%$ of the programmes listed in the Campusfrance brochure merely stipulate "fluent in" or "mastery of" English, in some cases making reference to standardised tests such as TOEFL, TOEIC or IELTS, but with no specification of a baseline acceptable score. Secondly, for these hundreds of programmes taught in English in France, $79 \%$ of them either make no mention of a required minimal level of French competency or specifically state that French is "not required". A certain level of French, favouring social integration and cultural knowledge, thus appears to be a low status concern. Given the traditional defence of la francophonie, the official position in the brochure stating that "Il n'est plus nécessaire de pratiquer couramment le français pour étudier en France" seems, at best, a paradoxical view of language acquisition. We have no access to evaluations of the programmes listed by Campusfrance - if such measures even exist -, but the kinds of recommendations seen in the CLIL literature leave room for scepticism.

29 A final observation of less than exemplary national language awareness appeared in an article published in Le Monde Magazine, November 13, 2010. In "Dans les facs, va-t-on passer au tout anglais?", it was explained how the national Ministry of Education is caught between the difficult task of preserving national identity ("le français est la langue de l'enseignement" according to the Loi Toubon) and the desire to make the most of globalisation. The president of one of France's largest universities of social sciences is quoted (p. 37) dismissing the questions of language policy and quality CLIL in claiming that 'L'anglais n'est qu'un véhicule, une langue mondiale, c'est tout. Je suis pragmatique. Ce n'est pas une question idéologique." The link between language and culture which forms the basis of French ESP research and has been documented for over thirty years, the notion of discourse communities - especially in social science domains like law, economics and management -, and the concept of transdisciplinary collaboration simply go unrecognised. One cannot generalise from the case of a single university president, but how many others, we wonder, regard CLIL in an equally perfunctory manner?

\section{ESP at the crossroads: new avenues of didactic reflection and practice}

30 As Tudor (2009: 25) puts it, "it would [...] be naïve to assume that this [effective realisation of CLIL based on theoretical and practical considerations] will occur without focused advocacy, including the willingness to address critically the issues...". In that spirit, what roles, from our own experience of nearly forty years in the Lansad sector of the French Éducation nationale, can ESP researchers and teachers play in a climate where language awareness appears to leave much to be desired? Our field, in France, 
has historically embraced the notion of mediation; such was the theme of the GERAS colloquium in 2001 (Bordeaux, ASp 31-33). In the French CLIL context, it is our belief at this point in time that the impetus for pedagogical and didactic reflection can only come from Lansad professionals, particularly in ESP, who understand both the "virtuous" and "vicious" challenges of CLIL, and who are willing and able to act as advocates. In the "can do" spirit of "my next language learning target" from the European language portfolio, ESP professionals are surely the most competent to accompany change management by raising the strategic questions of institutional language objectives, pedagogical approaches and means by which to reach objectives, as well as the evaluation of the entire process. Moreover, as a community, ESP teachers and researchers are, in most cases, accustomed to working from a bottom-up perspective; we thus have the unique responsibility of mediating among the different CLIL stakeholders in working towards institutional language policy. CLIL is, or should be, an explicit element of the latter.

31 How to go about such a challenging task? Firstly, colleagues advocating quality CLIL must, obviously, familiarise themselves with the ever increasing body of literature to link theory to effective practice..$^{12}$ Secondly, the visibility and implication of the Lansad team in university governance is important to gain the trust and confidence of both specialists of other disciplines and decision makers. From that positivist stance, CLIL question can then be addressed objectively, for example by means of a SWOT analysis (strengths, weaknesses, opportunities, threats). This well-known tool from the business world helps to set realistic objectives in light of both internal and external favourable and unfavourable environmental factors in any decision-making context; one does not have to be a management expert to gain inspiration from SWOT. Strengths (internal) are those inherent characteristics which give the institution or programme an advantage over others; weaknesses (internal), conversely, are those characteristics placing the institution at a competitive disadvantage. Opportunities (external) are chances to improve; threats (external) are possible causes for trouble, often linked to a changing environment. Figure 1, based on a local university, illustrates a SWOT analysis.

Figure 1: Example of a SWOT analysis

\begin{tabular}{|l|l|l|}
\hline & $\begin{array}{l}\text { HELPFUL } \\
\text { to achieving the objective }\end{array}$ & $\begin{array}{l}\text { HARMFUL } \\
\text { to achieving the objective }\end{array}$ \\
\hline
\end{tabular}




\begin{tabular}{|c|c|c|}
\hline $\begin{array}{l}\text { INTERNAL } \\
\text { ORIGIN } \\
\text { attributes of the } \\
\text { institution }\end{array}$ & $\begin{array}{l}\text { STRENGTHS } \\
\text { - a strong desire for international } \\
\text { recognition } \\
\text { - a devoted international relations } \\
\text { service } \\
\text { - a fairly international teaching staff } \\
\text { - a newly created quality service }\end{array}$ & $\begin{array}{l}\text { WEAKNESSES } \\
\text { - certitudes of key decision makers } \\
\text { about language acquisition = stop-gap } \\
\text { language provision, } \neq \text { coherent } \\
\text { language policy } \\
\text { - lack of an effective tradition of } \\
\text { meaningful self or external assessment } \\
\text { - traditional lack of interdisciplinary or } \\
\text { horizontal collaboration } \\
\text { - lack of knowledge/recognition of } \\
\text { research by language specialists (profile } \\
\text { difficult for dominant content } \\
\text { disciplines to decode) } \\
\text { - large number of "low status" (PRAG, } \\
\text { PRCE) language teaching personnel }\end{array}$ \\
\hline $\begin{array}{l}\text { EXTERNAL } \\
\text { ORIGIN } \\
\text { attributes of the } \\
\text { environment }\end{array}$ & $\begin{array}{l}\text { OPPORTUNITIES } \\
\text { - political alignment of local university } \\
\text { governance and central government, } \\
\text { leading to financial support for } \\
\text { pedagogical initiatives }\end{array}$ & $\begin{array}{l}\text { THREATS } \\
\text { - changes in local university governance } \\
\text { and central government creating } \\
\text { uncertainty in relations and affecting } \\
\text { institutional partnerships }\end{array}$ \\
\hline
\end{tabular}

Once such internal and external factors have been identified, the SWOT analysis is then used to set realistic objectives. Strategy for implementing CLIL can be defined according to a matrix stressing the notion of process, considering strengths and opportunities together to see how an institution can pursue the latter supported by the former. Looking at opportunities in terms of institutional weaknesses can point the way to overcoming the latter. Mobilising inherent strengths can help to limit vulnerability to external threats. Finally, considering external threats in terms of inherent weaknesses can help decision makers to think in terms of damage control, and might hopefully suggest directions for strengthening weaknesses.

Within their institutions, ESP professionals should start with the basic internal questions of what is already being done, what is planned or what might be imagined regarding CLIL. What are ESP professionals' political and personal roles or impact in decision-making processes, both within the institution and within larger structures such as recent "confederations" of French universities (Pôles de recherche et d'enseignement supérieur, PRES)? Externally, in a rapidly changing environment, how is the current institutional situation evolving in terms of initiatives of international excellence in research and teaching (Idex, Labex) and the PRES?

Pertaining directly to CLIL, several questions then need to be asked concerning pedagogy in general and ESP didactics in particular. The key concept, in the spirit of mediation, is collaboration, particularly with content teachers who are generally unaware of language considerations, but also with decision makers in order to secure the indispensable political mandate to mediate. Since objective hard data are a key tool in encouraging institutional change, a well thought-out institution- (or PRES-)wide survey will provide irrefutable explicit, written evidence and answers. In the era of performance measurement, we strongly recommend collaboration with university 
quality services such as the Bureau d'aide à l'insertion professionnelle and the Observatoire de la vie étudiante.

Based on the literature and on results from projects such as LANQUA, rubrics to cover should follow the aforementioned key CLIL variables (LANQUA Frame of Reference: 12). Specific questions, by rubric, should address:

- Main aims: what are the explicit reasons for implementing CLIL? Is it planned to be truly dual focus (i.e., are there explicit objectives and learning outcomes for both content and language learning)? How are these defined?

- Target group: at what level(s) of study? For French nationals as well as international students? For non-native as well as native speakers?

- Main actors: which teachers/administrators will be involved and in what capacity? How will teaching staff be selected/recruited? Is any incentive offered to teachers undertaking CLIL? What content/language selection process will there be for students?

- Pedagogical approach: first and foremost, what form of CLIL, according to the CLIL continuum, is to be implemented? The answer to this question necessarily determines the pedagogical approach adopted and the didactic translation of same. Thus, while distinct ESP classes, for example, can only be considered as pre-CLIL, a languageoriented partial CLIL context implies respect on the part of the language teacher of domain-specific epistemology, terminology and oral and written discourse - the fibre of anglais de spécialité (ASP) as defined by the Commission formation de la SAES in 2011 ("l'expression d'un domaine spécialisé dans cette langue [... et] qui étudie cet objet et [...] développe la réflexion didactique propre à son enseignement et son apprentissage" (see References). Language-oriented partial CLIL also points favourably towards collaboration with content teachers. Discipline-driven partial CLIL, on the other hand, may constitute a real challenge since language aims and outcomes are generally taken for granted in an environment where there is no language instruction and where collaboration in any form with content teachers is rare.

40 If, however, adjunct CLIL is the model, didactic issues can be clearly and freely addressed, theoretically in collaboration with content teachers: in function of students' needs, what relative weight will be given to receptive and productive competences in order to develop the skills needed for content mastery? How will the specific role of language be assessed by the language teacher (i.e., without drawing on students' knowledge of the disciplinary domain)? Or will there be joint criteria adopted by both content and language teachers in their respective assessments? In this form of CLIL, students must receive credits for both language and content classes.

41 If the CLIL in question is fully integrated and dual focus, taught either by a truly language-competent content teacher or by a team of language and content specialists, then the field of didactic questions is even wider: what approaches are to be favoured in the classroom ("top-down" lecturing, interactive methods, group work, student presentations, reading assignments, writing assignments, class participation, blended learning, e-learning)? What challenges will they represent for students from varying language and cultural origins (strategies for listening, reading, writing, speaking, notetaking; learning appropriating discourse conventions and vocabulary)? Is plagiarism likely to be a cultural problem? What feedback will there be for teachers? What adaptations might be necessary for teaching materials? Assessment may take multiple forms, but must include mutually established content and language aims. 
42 the embodiment of disciplinary expertise itself? What balance will be defined between target language fluency and accuracy?

43 - Assessment: what forms will be appropriate, and materially possible? How will both content and language mastery be handled (i.e., collaboration of content and language specialists)?

- Implementation: what kind of interdisciplinary collaboration is possible between content and language teachers (programme design, materials design, assessment, team teaching)? What three-way collaboration will there be with decision makers? What role will the different stakeholders (academic senate, programme director, teaching staff, students) have (i.e., who is responsible and accountable for what)? What administrative infrastructure and support will there be? What language/pedagogical/intercultural support can be offered for content teachers undertaking CLIL? Is content-related support available for language specialists? What language or study skills support is offered to students, and when (pre-sessional, in parallel to content courses?) What formative evaluation procedures will be put into place?

\section{Conclusion: the key role of ESP specialists}

Readers may perhaps see our rather lengthy list of questions to explore in encouraging CLIL as overwhelming, a SWOT analysis as impossible to carry out and the local example of internal weaknesses, for example, as too "pessimistic". Our many years observing HE in France and participating in pedagogical and didactic exchanges in an international context, however, have shown us that constructive reflection can indeed be institutionally implemented from a bottom-up perspective, followed by appropriate action (often in an action research context), as long as the playing field is clearly understood.

Individual institutions, of course, have their own ethos and characteristics, depending on, among other things, their status and disciplinary culture(s). But certain characteristic French (and in part, Latin) historical and national traditions do exist. They are described in similar ways by intercultural researchers working in different contexts (Hall 1977; Hofstede 1991; Hickson \& Pugh 1995; D'Iribarne 1998, 2006) and need to be understood and acknowledged to work towards the collegial, "Northern European" model that successful CLIL represents in international quality assessments. Among such identified possible challenges to implementation of CLIL in France are, for example, the propensity for a theoretical rather than an applied or practical approach to learning and study. This includes the concept of foreign language acquisition and language teacher training designed to implement the latter. The notion of HE language policy in this context is thus a difficult concept, reinforced by the "delicate" question of defending la francophonie in the face of the hegemonic English as a lingua franca. A further logical extension of this theoretical orientation is the less than "noble" status of language teaching and research in the Lansad context compared to that of more traditional disciplines, making collaboration on an equal footing potentially difficult between discipline and language specialists. Added to this is the "silo" mentality of parallel disciplines where cross-"border" collaboration does not play a traditional role, ${ }^{13}$ and where CLIL may conveniently be seen as a simple economy of scale. A final characteristic of French HE which makes feedback on quality CLIL a challenge is the 
lack of tradition for systematic institutional internal and external formative assessment. Ministerial efforts have been made for several years in this direction, but the top-down, prescriptive and summative spirit, particularly of recent measures under the government in power from 2007 to 2012, did little to encourage the reciprocal confidence and accrued language awareness which effective CLIL requires.

As a concluding remark, guiding institutions along the route towards adjunct or dual focus CLIL, seen as a crossroads of content and language, of ESP and didactic reflection within the framework of an explicit language policy, will require long-term advocacy on the part of Lansad professionals. This means first exploring the international savoir and savoir-faire of effective (and less effective) CLIL. The European Language Council/ Conseil européen pour les langues - the driving force behind the aforementioned ENLU and LANQUA projects, also involved in the Council of Europe's European Centre for Modern Languages (ECML)/Centre européen pour les langues vivantes (CELV) -, for example, offers different possibilities for research and practice. With internationally validated expertise of this type, ESL specialists should more easily be able to "infiltrate" university governance on a policy level (LANQUA Toolkit material was developed with that aim) as well as disciplinary communities, offering "novel" concrete suggestions such as language support for teachers or guiding online writing assistance with the TYOS programme. The (mostly) positive examples of the Toulouse universities' parcours bilingues on a Bachelor's level are noteworthy examples of such "infiltration". The CLIL field, once opened up, can then offer a multitude of possibilities for quantitative and qualitative (action-)research using a number of analytical tools (questionnaires, interviews, etc.).

Encouraging the implementation of effective CLIL is a major challenge, but the fruit of several decades of French ESP research and expertise in various domain-specific epistemologies, cultures, terminologies and discourse bodes well for such an undertaking. Change management takes time, so the words of the well-known Serenity prayer ${ }^{14}$ may perhaps stave off frustration for colleagues, aware of local and national culture but also of the demands of quality CLIL reflected in international research and practice: "...the serenity to accept the things I cannot change, the courage to change the things I can, and the wisdom to know the difference".

We would like to thank the two anonymous referees for their helpful comments and suggestions in preparing this text for publication.

\section{BIBLIOGRAPHY}

Bartik, Kristin et alii. 2009. "A discussion brief of content and language integrated learning (CLIL) at the faculty of Applied Sciences [University of Cordoba]. <http://www.uco.es/poling/ multilingualism_plan/?p=69>.

Burger, Sandra et alii. 2011. "French immersion studies at the University of Ottawa: Programme evaluation and pedagogical challenges". In Tedick, D. J, D. Christian and T. Williams Fortune 
(eds.), Immersion Education. Practices, Policies, Possibilities. Multilingual Matters: Bristol, UK. 123-142.

Causa, Mariela, Martine Derivry-Plard, Brigitte Lutrand-Pezant \& Jean-Paul Narcy-Combes (eds.). 2012. Les langues dans l'enseignement supérieur. Quels contenus pour les filières non linguistiques? Paris: Riveneuve.

Coleman, James A. 2006. "English-medium teaching in European higher education". Language Teaching 39/1, 1-14. DOI : 10.1017/S026144480600320X, published online : 10 July 2006.

Council of Europe, 2002. Common European Framework of Reference for Languages: learning, teaching, assessment. <http://www.coe.int/t/dg4/linguistic/Cadre1_en.asp>.

D’Iribarne, Philippe. 1989. La Logique de l'honneur : gestion des entreprises et traditions nationales. Paris: Seuil.

D’Iribarne, Philippe. 2006. L'Étrangeté française. Paris: Seuil.

Flowerdew, John and Lindsay Miller. 1995. "On the notion of culture in L2 lectures". TESOL Quarterly 2, 345-373.

Hall, Edward. T. 1977. Beyond Culture. New York: Anchor/Doubleday.

Hansen-Pauly, Marie-Anne and Greere Anca. 2011. "Rising to the challenge: English in the internationalization of higher education across Europe". The European English Messenger 20/1, 27-28.

Hellekjaer, Glenn Ole and Robert Wilkinson. 2003. "Trends in content learning through English at universities: A critical reflection". InVan Leeuwen, C. and R. Wilkinson (eds.), Multilingual Approaches in University Education: Challenges and Practices. Nijmegen: Uitgeveerij Valkhof Pers \& Talencentrum Universiteit Maastricht.

Hickson, David J. and Derek S. Pugh. 1995. Management Worldwide. London: Penguin.

Hofstede, Gert, 1991. Cultures and Organizations: Software of the mind. London: McGraw-Hill.

Joy, Simy and David A. Kolb. 2009. “Are there cultural differences in learning style?". International Journal of Intercultural Relations 33, 69-85.

Knoerr, Hélène. 2010. «L'immersion au niveau universitaire : nouveaux modèles, nouveaux défis, pratiques et stratégies ». Les Cahiers de l'ILOB/OLBI Working Papers 1/1, 89-110.

Le Monde Magazine. 13 novembre 2010, 36-40.

Maiworm, Friedheim and Bernd Wächter. 2002. English-language-taught Degree Programmes in European Higher Education, Trends and success factors. Bonn: Lemmens Verlags \& Mediengesellschaft.

Marsh, David and Jenni Laitinen. 2004. "Discussion brief” ENLU Task Force 4 - Medium of Instruction. <http://web.fu-berlin.de/enlu/documents.htm.

Mémet, Monique. 2003. «L'enseignement à contenu intégré augmente la motivation pour l'apprentissage de la langue : vrai ou faux ? Étude portant sur des cours d'anglais de spécialité en médiation culturelle". ASp 39-40, 131-142.

Räsänen, Anne. 2011a. "International classrooms, disciplinary cultures and communication conventions: A report on a workshop for content and language teachers". Quality Assurance Review for Higher Education 3/2, 155-162. <http://www.aracis.ro/en/publicatii/qar-magazine/numarulcurent>. 
Räsänen, Anne. 2011b. "Quality of English-medium teaching from the perspective of language. The TACE Programme. University of Jyväskylä Language Centre”. (conference presentation available from G. Taillefer). See <https://kielikeskus.jyu.fi/henkkoul/tace/tace> for examples of TACE modules.

Räsänen, Anne. 2011c. "The promise and challenge of CLIL (Content and Language Integrated Learning) as a mediator for internationalisation". Presentation at the European Council/Polish Ministry of National Education conference on "Multilingual Competences for Professional and Social Success in Europe", Warsaw, 28-29 September $2011<$ www.celelc.org/docs/ rsnen_-_warsaw_0.pdf>.

Räsänen, Anne and Renate Klaassen. 2006. "From learning outcomes to staff competences in integrated content and language instruction at the higher education level". In Wilkinson, R., V. Zegers and C. van Leeuwen (eds.), Bridging the Assessment Gap in English-medium Higher Education. AKS-Series: Fremdsprachen in Lehre und Forschung. Bochum: AKS-Verlag, 256-280.

Taillefer, Gail. 2004. « Enseigner une matière disciplinaire en langue étrangère dans le contexte français des sciences sociales : défi, observations et implications ». ASp 45-46, 111-126.

Taillefer, Gail. 2005a. "Reading for academic purposes: The literacy practices of British, French and Spanish Law and Economics undergraduates studying in their own country and abroad". Journal of Research in Reading 28/4, 435-451.

Taillefer, Gail. 2005b. "Foreign language reading and study abroad: Cross-cultural and crosslinguistic questions". The Modern Language Journal 89/4, 503-528.

Taillefer, Gail. 2009a. « EMILE en France : quelle offre ? quelles perspectives ? ». Les Après-midi de LAIRDIL 15, 29-40.

Taillefer, Gail. 2009b. « EMILE ‘à la canadienne' : le Régime d'immersion en français de l'Université d'Ottawa. » Les Après-midi de LAIRDIL 15, 41-54.

Taillefer, Gail. 2009c. « EMILE ‘à la finlandaise’ : English-medium Master’s programmes ». Les Après-midi de LAIRDIL 15, 63-68.

Taillefer, Gail. 2009d. « Résumé des échanges : enseignants disciplinaires et enseignants de langues ». Les Après-midi de LAIRDIL 15, 55-62.

Taillefer, Gail 2011. “Developing Romanian international master's level education: Reflections on change management". Quality Assurance Review for Higher Education 3/2, 126-133. <http:// www.aracis.ro/en/publicatii/qar-magazine/numarul-curent>.

Truchot, Claude. 2010. «L'enseignement supérieur en anglais véhiculaire : la qualité en question ». <http://www.diploweb.com/spip.php?article686>.

Tudor, Ian 2006. "Trends in higher education language policy in Europe: The case of English as a language of instruction". Paper presented at the conference Challenges of Multilingual Societies, ECORE, Université Libre de Bruxelles 9-10 June, 2006 (non published, reprint available from G. Taillefer).

Tudor, Ian 2007. "Higher Education language policy in Europe: From principle to practice". Language Teaching and Learning in Multicultural and Plurilingual Europe. Vilnius: Vilniaus universiteto leidykla, 41-50 (available from G. Taillefer).

Tudor, Ian 2008. "The language challenge for higher education institutions in Europe, and the specific case of CLIL". In Marti i Castell, J. \& J. M. Mestres i Serra (eds.), El Multlingüisme a les Universitats el l'Espai Europeu d'Educacio Superior. Barcelona: Institut d'Estudis Catalans, 42-64. 
Tudor, Ian 2009. "Content and language integrated learning (CLIL)in higher education in Europe: an overview of practice and lines for investigation”. Les Après-midi de LAIRDIL 15, 9-27.

Wächter, Bernd and Friedhelm Maiworm. 2008. English-taught Programmes in European Higher Education. The picture in 2007. Bonn: Lemmens.

Weinberg, Alysse and Sandra Burger. 2007. Guide à l'intention des professeurs de langue: Cours d'encadrement linguistique. Ottawa: Official Languages and Bilingualism Institute (available from $\mathrm{G}$. Taillefer).

Weinberg, Alysse, Sandra Burger and Amelia Hope. 2008. "Evaluating the effectiveness of content-based language teaching". Contact 34/2 [Research Symposium Issue], 68-80. <http:// www.teslontario.net/publications/research-symposium-2/>.

Wolff, Dieter. 2003. "Integrating language and content in the language classroom: Are transfer of knowledge and of language ensured?". ASp 41-42, 35-46.

Yamazaki, Yoshitaka. 2005. "Learning styles and typologies of cultural differences: A theoretical and empirical comparison". International Journal of Intercultural Relations 29, 521-548.

For further information on CLIL, while oriented to primary and secondary education see also: CLIL Compendium <http://www.clilcompendium.com/clilcompendium.htm>.

Dalton-Puffer, Christiane. 2008. "Outcomes and processes in content and canguage integrated learning (CLIL): Current research from Europe”. In Delanoy, W. and L. Volkmann (eds), Future Perspectives for English Language Teaching. Heidelberg: Carl Winter, 139-157.

Eurydice. 2006. "Content and Language Integrated Learning (CLIL) at School in Europe”. Brussels: European Commission. <http://www.eurydice.org/ressources/eurydice/pdf/_integral/ 071EN.pdf>.

Geiger-Jaillet, Anemone, Gérald Schlemminger and Christine Le Pape Racine. 2011. Enseigner une discipline dans une autre langue : méthodologie et pratiques professionnelles. Frankfurt: Peter Lang. (Édité par le Centre européen pour les langues vivantes [CELV] dans le cadre du français langue étrangère).

Marsh, David, Peeter Mehisto, Dieter Wolff and Maria Jesus Frigols Martin. 2010. European Framework for CLIL Teacher Education. Strasbourg-Graz: Council of Europe-European Centre for Modern Languages <http://clil-cd.ecml.at/Portals/24/flashfiles/index3.html>.

Snow, Marguerite A. and Donna M. Brinton (eds.). 1997. The Content-Based Classroom. White Plains, NY: Addison-Wesley Longman.

Stoller, Frederika and William Grabe. 1997. “A Six-T's approach to content-based instruction”. In Snow, M. and D. M. Brinton (eds.), The Content-Based Classroom. White Plains, NY: Addison-Wesley Longman. A composite vision of exemplary models of CLIL.

University of Cambridge ESOL Examinations. "Teaching Knowledge Test (TKT)”. A test of professional knowledge for English language teachers and also subject teachers who use English as a medium for teaching their curriculum subject: Teacher's handbook $<\mathrm{http}: / /$ www.cambridgeesol.org/assets/pdf/exams/tkt/tkt-handbook.pdf>.

Online references - Retrieved in November 2012

Cahiers de l'ILOB/OLBI Working Papers. <http://www.ccerbal.uottawa.ca/cahiers.php?lang=eng>. Campusfrance <http://www.campusfrance.org>.

Commission de formation SAES. <http://www.saesfrance.org/Profession/Commissionformation>. 
Emilangues (site de référence pour les sections européennes ou de langues orientales). <http:// www.emilangues.education.fr/>.

European Association for Quality Assurance in Higher Education (ENQA). <http://www.enqa.eu>

European Centre for Modern Languages (ECML)/Centre européen pour les langues vivantes (CELV). <http://www.ecml.at/>.

European Language Council/Conseil européen pour les langues. <http://www.celelc.org>.

European Network for the promotion of Language learning among all Undergraduates (ENLU), 2004-2006. <http://web.fu-berlin.de/enlu>.

Integrating of Content and Language in Higher Education Association (ICLHE). <http://

www.iclhe.org>.

Language Network for Quality Assurance project (LANQUA), 2007-2010. <http://www.lanqua.eu>.

Official Languages and Bilingualism Institute/Institut des langues officielles et du bilinguisme (OLBI/ILOB). <http://www.olbi.uottawa.ca>.

Sharing Practice in Enhancing and Assuring Quality (SPEAQ). <http://

speaqproject.wordpress.com>.

SWOT analysis, see, for example, <http://en.wikipedia.org/wiki/SWOT_analysis> and <http:// www.quickmba.com/strategy/swot/>.

Type your own script (TYOS). <http://www.tyos.org>.

University of Jyväskylä language policy. <https://www.jyu.fi/hallinto/strategia/en/universityof-jyvaskyla-language-policy-2012/view>.

University of Toulouse-1 Capitole Licence en droit : parcours droit et langue anglaise. <http:// www.ut-capitole.fr/formations/nos-diplomes/licences/licence-l1-l2-l3-droit-parcours-droit-etlangue-anglaise-310293.kjsp?RH=1319186509588>.

University of Toulouse-1 Capitole parcours droit et monde hispanique. <http://www.utcapitole.fr/formations/nos-diplomes/licences/licence-l1-l2-l3-droit-parcours-droit-et-mondehispanique-310287.kjsp?RH=1319186509588>.

University of Toulouse-le Mirail parcours bilingues History and English. <http://www.univtlse2.fr/accueil-utm/formation/offre-de-formation/licence-histoire-parcours-bilingueanglais--177761.kjsp?RH=02Diplomes>.

University of Toulouse-le Mirail parcours bilingue History and Spanish. <http://www.univtlse2.fr/accueil-utm/formation/offre-de-formation/licence-histoire-parcours-bilingueespagnol--177762.kjsp?RH=02Diplomes>.

\section{NOTES}

1. CLIL, language learning, intercultural communication, foreign language literature and language teacher education. The network is being followed up by the SPEAQ project (Sharing Practice in Enhancing and Assuring Quality), aimed at connecting three key quality circles teacher, student and quality manager - to share and enhance quality assurance in HE, including CLIL.

2. Of particular note for French readers is the Italian case study on exemplary collaboration between content and language teachers in a Southern European context. 
3. In French HE, the most common term is EMILE, enseignement d'une matière par l'intégration d'une langue étrangère or intégré à une langue étrangère, and in the secondary sector, DNL (discipline non linguistique).

4. For a graphic representation, see Räsänen 2011c. This continuum was first developed by Räsänen in 2008 in the early stages of LANQUA.

5. The 1945 novel by Canadian author Hugh MacLennan on relations between English and French-speaking Canadians.

6. In our experience, these two concepts are rarely clearly distinguished in French HE. Neighbouring francophone Swiss and Belgian CLIL contexts generally refer to these terms, respectively, as apprentissages larges/précis, attendus and acquis des formations or résultats visibles.

7. For a recent echo, see Le Monde, "La mort programmée des cours en 'amphi”, October 11, 2012.

8. The site of Emilangues (see References) offers limited historical insight.

9. An online publication, so no page number can be given.

10. Some, however, are challenged in their use of French.

11. For an earlier picture, see Taillefer 2009a.

12. Useful references other than those directly cited herein also figure at the end of the text.

13. The division of knowledge into distinct CNU sections is perhaps the prime example, as is obligatorily registering doctoral research in a specific discipline.

14. Attributed to theologian Reinhold Niebuhr, 1943.

\section{ABSTRACTS}

With the increasing internationalisation of higher education, Content and Language Integrated Learning (CLIL) has become an object of both teaching and research. Varying international contexts now offer examples of effective practice and theoretical models incorporating complex and pertinent quality criteria such as national and institutional language policy, CLIL pedagogy and didactics and specific roles of different stakeholders (institutions, content and language teachers, students). France is a relatively recent player in this field and will be seen, through examples and comparison, to reflect less than optimal awareness of these key quality issues. Research (Coleman 2006; Bartik et alii 2009) suggests that poor quality CLIL can result from marginalising higher education language specialists in the implementation process. The French ESP sector stands at the CLIL crossroads between content and language with a natural role to play as mediator in encouraging interdisciplinary reflection linking theory and effective practice. The aim of this paper is to share current international work on CLIL with members of the ESP community and to suggest by means of a SWOT analysis ways to integrate pertinent reflection and practice at the CLIL crossroads.

Avec l'internationalisation croissante de l'enseignement supérieur, l'Enseignement d'une matière intégré à une langue étrangère (EMILE) est devenu un objet à la fois d'enseignement et de recherche. Différents contextes internationaux fournissent des exemples de pratiques efficaces et des modèles théoriques qui incorporent des critères de qualité complexes et pertinents, tels qu'une politique linguistique institutionnelle ou nationale, une pédagogie et une didactique de l'EMILE et des rôles spécifiques des différents acteurs (institutions, enseignants disciplinaires et de langue, étudiants). La France s'intéresse à l'EMILE depuis relativement peu de temps et elle n'est pas très sensibilisée à ces questions clés liées à la qualité. Les travaux de recherche 
indiquent qu'une mise en œuvre défaillante de l'EMILE peut découler de la marginalisation des spécialistes de langue de l'enseignement supérieur. Le secteur ASP/Lansad se trouve au carrefour de l'EMILE entre les disciplines et les langues; il joue un rôle naturel de médiateur transdisciplinaire axé sur le lien entre théorie et pratique efficace. L'objectif de la présente réflexion est de partager avec la communauté ASP des travaux internationaux récents sur l'EMILE et de suggérer à travers une analyse SWOT une manière d'intégrer une réflexion et une pratique pertinentes à cette forme de pédagogie.

\section{INDEX}

Mots-clés: analyse SWOT, ASP/Lansad, conscience linguistique, didactique, EMILE, théorie et pratique

Keywords: CLIL, didactics, language awareness, LSP, SWOT analysis, theory and practice

\section{AUTHOR}

\section{GAIL TAILLEFER}

Gail Taillefer is Emeritus Professor of English from the University of Toulouse 1 Capitole and a researcher at LAIRDIL (Laboratoire interuniversitaire de recherche en didactique des langues). Her most recent work, both in France and abroad, has dealt with questions of language policy, notably CLIL. She founded and directed the Toulouse 1 Language resource centre.

gail.taillefer@ut-capitole.fr 